\title{
TUMOR ODONTOGÊNICO CERATOCÍSTICO EM REGIÃO ANTERIOR DE MANDÍBULA
}

Roberta Targa STRAMANDINOLI; Andressa SEMPREBOM; Wilson Denis MARTINS; Marina Oliveira RIBAS

Será relatado um caso de Tumor Odontogênico Ceratocístico em paciente feminino, melanoderma, 14 anos de idade. A paciente apresentava assimetria facial, aumento de volume na região de mento, deslocamento dentário e telangiectasia local. Com aspecto radiolúcido em diferentes densidades, estendia-se do segundo molar direito ao primeiro molar do lado oposto, com a presença de canino incluso no interior. Foi realizada a colocação de dreno para descompressão da lesão cística e subseqüente enucleação com curetagem óssea. A paciente encontra-se em acompanhamento sem sinais de recidiva. 